DOI 10.18551/rjoas.2021-04.19

\title{
STRATEGY OF BUSINESS MANAGEMENT FISH FARMING IN FLOATING NET CAGES IN BANJAR DISTRICT, SOUTH KALIMANTAN OF INDONESIA
}

\author{
Asharurozi ${ }^{\star}$, Student \\ Doctoral Program of Agricultural Science with an Interest in Natural Resources and \\ Environmental Management, University of Lambung Mangkurat,Banjarbaru, Indonesia \\ Mahyudin Idiannor, Mahreda Emmy Sri \\ Study Program of Fisheries Socio-economics, Faculty of Fisheries and Marine Affairs, \\ University of Lambung Mangkurat, Banjarbaru, Indonesia \\ Priatmadi Bambang Joko \\ Faculty of Forestry, University of Lambung Mangkurat, Banjarbaru, Indonesia \\ *E-mail: asharurozi123@gmail.com
}

\begin{abstract}
Fish farming in floating net cages is a cultivation method developed in public waters in Banjar Regency. The application of cultivation management by paying attention to the carrying capacity (carring capacity) of the environment is one of the efforts to ensure that these activities are sustainable. The problem with this research is that the current management still needs to determine a strategy that is in accordance with the potential and carrying capacity of the environment. The purpose of this study is to determine the strategy of floating net cage cultivation in Banjar Regency, then to determine priorities based on the Quantitative Strategies Planning Matrix (QSPM) analysis and management implications. This type of research is a descriptive study, with a case study method (case study). Based on the SWOT analysis, the strength (S) which has a big influence on the management of the floating net cage cultivation business in Banjar Regency is the value and volume of production (0.54), while the biggest weakness (W) is human resources and farmer participation in controlling fish farming in net cages. Floating (0.24), and the biggest opportunity $(\mathrm{O})$ is fish cultivator institutional activity (0.37), and the biggest threat $(T)$ is Airflow Control Conflict (0.25). Based on the QSPM analysis, the Total Attractive Score (TAS) obtained the main strategic priority, namely the WO1 Strategy (TAS $=6,964)$, namely increasing the competence and professionalism of human resources through management implications in the form of routine and periodic counseling activities, while the last choice strategy is the WO3 strategy (TAS = 6,780 ), namely utilizing human resources to increase cultivation production through participatory activities, cooperation and mutually beneficial partnerships.
\end{abstract}

\section{KEY WORDS}

Strategy, management, floating net cage cultivation, continuous.

The cultivation of fish in cages in the Riam Kanan River has developed rapidly and has great potential for development. The absence of regulation on this activity is the cause of uncontrolled growth of the cages fishery business. This condition is also a common phenomenon in small-scale aquaculture businesses in Asian countries, causing environmental problems and difficulties for further planning, management and development (White et al. 2013).

The potential that is owned is expected to have a welfare impact on the community, but this can be realized if the community participates in managing aspects of fish farming in good cages. Fish farming in watersheds has special characteristics compared to fish farming in other places, where the productivity is determined by the carrying capacity of the relevant aquatic environment. The carrying capacity of the aquatic environment is the ability of the aquatic environment to support the survival of a number of fish naturally in a habitat. 
Therefore the cultivation system that takes into account the carrying capacity of the aquatic environment in determining the scale of the cages business unit to ensure continuity of harvest is known as a sustainable cultivation system.

According to (Siagian, 2010), the watershed area of the reservoir is said to be appropriate for fish cultivation in the floating net cage system, if the environmental conditions of the waters can support the life and life of the cultivated organism. good fish growth (optimal production). To achieve optimal production, especially in Banjar Regency, it is necessary to have a management strategy (location, number and types of fish cultivated, amount and type of feed given, and business period) in connection with reservoir water fluctuations (Chandra et.al, 2018).

Strategy according to (Rangkuti, 2013), is defined as a tool to achieve company goals in relation to long-term goals, follow-up programs and priority allocation of resources. Meanwhile, according to (David, 2011), management strategy is the art and science of formulating, implementing and evaluating cross-functional decisions that enable an organization to achieve its goals.

The Banjar Regency Government through the Fisheries Office revealed that the number of cage units has decreased from year to year. 2001 - 2020 period from 6,800 units to 2,350 or a decrease of \pm 222 units per year. The decrease in the number of cage units cultivated by the population is due to the high mortality of cultivated fish. This reached its peak on 15-20 October 2019 when the fish raised in cages along the Riam Kanan River experienced mass deaths due to reduced water quality. Other causes include damage to cages and loss of raised fish due to flooding that occurs every year. This death is very detrimental to fish farmers due to the exceeding carrying capacity of the waters, a natural phenomenon that tends to repeat itself in the future (Banjar Regency Fisheries Service, 2020).

The management of fish farming in floating net cages must be carried out based on the application of Best Management Practices (BMP) which pay attention to the correct cultivation principles and pay attention to the carrying capacity of the existing aquatic environment, because without this, the management of floating net cages will not succeed. So that at this time a policy review and supervision is needed on the management strategy of floating net cage cultivation to obtain appropriate policy recommendations. Until now, there has been no adequate analysis of the possibility of managing fish farming in floating net cages in Banjar Regency so that these activities are sustainable both from the bio-technical and socio-ecological aspects.

The purpose of this study was to determine the management strategy for fish culture in floating net cages based on a SWOT analysis and then determine the priority strategies based on the Quantitative Strategies Planning Matrix (QSPM) analysis and the management implications that must be carried out. The study on the management strategy of fish culture in floating net cages that is in accordance with the potential and carrying capacity of the environment will be useful as a reference for the local government of Banjar Regency in formulating a policy strategy for the management of aquaculture in floating net cages. The target of this research is to conserve and utilize the potential of public waters by managing the aquaculture of floating net cages that are environmentally friendly, sustainable and sustainable.

\section{METHODS OF RESEARCH}

Primary data were collected through field surveys and interviews with respondents using a questionnaire. Respondents came from the Fishery Household Group (67 FHG), 3 community leaders, the Village Head, the Public Works and Public Housing Office of the Republic of Indonesia Office, Environmental Agency, Development Planning Agency, Regional Research and Development, Fisheries Service Banjar Regency and academics, selected purposively. Secondary data are obtained from literature or documents both published and unpublished related to the research theme. 
The descriptive analysis is based on facts, then collected into an information that is used for further analysis and determination of future fish farming management strategies in floating net cages. Strategy analysis in the form of steps to develop a strategy for managing fish farming in floating net cages in Banjar Regency, namely:

a. Environmental Analysis. Identifying internal and external environmental factors that influence the management of fish farming in the floating net cages in Banjar Regency. The result is an element of strength and weakness as an internal strategic factor, as well as an element of opportunity and threat as an external strategic factor. The data are tabulated in the IFE (Internal Factor Evaluation) and EFE (External Factor Evaluation) matrices.

The highest possible total weight score for an organization is 4.0 and the lowest weight score is 1.0. The mean total weight score was 2.5. A total weight score of 4.0 indicates that an organization is effectively able to take advantage of opportunities and minimize the potential negative effects of external threats. A total score of 1.0 indicates that the company's strategy is unable to take advantage of existing opportunities or avoid existing threats.

b. SWOT analysis. The strategy method that is often used is SWOT analysis (Strengths, Opportunities, Weaknesses, Threats), in which analysis can be considered the most basic method, useful for looking at a topic or problem from four different sides. The results of the analysis are usually directions or recommendations to maintain strength and increase the benefits of existing opportunities, while reducing shortages and avoiding threats. David (2011) states that SWOT analysis is an important matching tool that helps managers develop four types of strategies namely: SO (strength-opportunity), WO (weaknessopportunity), ST (strength-threat), and WT (weakness-threat).

SWOT analysis combines various factors of strengths, weaknesses, opportunities and threats. The results can provide a number of solutions that can be used for the management of fish farming in floating net cages in Banjar Regency.

c. QSPM analysis. QSPM (Quantitative Strategic Planning Matrix) analysis is an analysis used to determine the relative attractiveness of various strategies based on how far the internal and external critical success factors are utilized or enhanced. David (2007) makes several steps to develop QSPM, namely: Creating internal and external lists of IFE and EFE matrices; Give weight to internal and external factors; Examine matching matrices and identify alternative strategies that the organization is considering implementing; Determine the Total Attractiviness Score (TAS) which is defined as a number that shows the relative attractiveness of each strategy in a certain set of alternatives by considering certain factors. The ranges of the TAS are: 1 = unattractive; 2 = somewhat interesting; $3=$ reasonable attractive; and $4=$ very interesting. Total TAS reveals the most attractive strategies in each set of alternatives.

\section{RESULTS AND DISCUSSION}

Current Condition of Floating Fish Cultivation (Existing Condition). The floating marine cage is a cultivated fishery commodity developed in Banjar Regency. The development of floating net cultivation activities in Banjar Regency is currently using simple maintenance and cultivation methods to intensive technology. The cages area is a coastal boundary on the mainland which is directly adjacent to the water area. The land use pattern for cages in Banjar Regency, seen from the administrative boundary of the pond area, is located in the Riam Kanan sub-watershed area, Karang Intan sub-district, Banjar district, South Kalimantan province consisting of 4 (four) villages, namely Sungai Asam (upstream), Sungai Alang and Sungai Landas (center), Arpat River (downstream). This affects the ability of the aquatic environmental conditions and the carrying capacity of the cages. The areas around the ponds in Banjar Regency, which have a direct or indirect impact on the floating net cages area, are rivers (as a supply of fresh water), open land, agriculture (rice fields, potential as a pesticide polluter), and human settlements (potential as a polluter. from household waste products).

Banjar Regency has the potential of waters in Banjar Regency is 9,730 ha with a water surface area of $92 \mathrm{~km}^{2}$. The waters of this reservoir include 9,200 ha of Riam Kanan 
Reservoir and $530 \mathrm{Ha}$ of Mandikapau Reservoir. Apart from being used for fishing activities, this area also functions as a boat base and aquaculture business. Fish farming activities that have been developed are fish farming in floating nets and cages. Based on data from the Production Sector, 1,251 floating net units in an area of +2 ha from an area of 376 ha are allowed for fisheries activities (Strategic Plan of the Banjar Regency Fisheries Service, 2020). The development of land use as a floating net cage cultivation area in Banjar Regency is the most significant in Karang Intan District. Percentage of pond cultivation area is $35.07 \%$ of the administrative area. Besides being cultivated through traditional methods. Some of these intensive ponds are located in Karang Intan sub-district based on the map of land use for aquaculture, the area of ponds in Banjar Regency is around 1775 hectares with an average area of concession area in one area is 44 ha. The area of aquaculture in Banjar Regency is $99.6 \%$ of the total area of cultivation land (Statistics on Aquaculture of Banjar Regency, 2020), this makes it a prospective fishery potential for floating net cages to be developed. From the existing conditions, it is known that the fish cultivation for floating net cages in this area has not been developed optimally.

Profile of Floating Net Cages In Banjar District. The development of floating net cages in Banjar Regency, from an economic point of view, is generally not optimal. The production volume of floating net cages in Banjar Regency from 2017 to 2020 tends to fluctuate, while the production value from 2017 to 2020 continues to increase. This can be seen from the volume and value of fish production in several sub-districts in Banjar Regency which are presented in Table 1.

Table 1 - Volume and Value of Production of floating net cages in Banjar Regency

\begin{tabular}{lll}
\hline Years & Volume $(\mathrm{kg})$ & Value(IDR.000) \\
\hline 2017 & 2.680 .000 & 5.896 .000 .000 \\
2018 & 2.530 .000 & 6.072 .000 .000 \\
2019 & 2.480 .000 & 6.200 .000 .000 \\
2020 & 2.348 .000 & 6.339 .600 .000 \\
\hline
\end{tabular}

Source: Department of Marine Affairs and Fisheries, Banjar Regency (2021).

Strategic Environmental Analysis for the Development of Fishnet Cage Cultivation Using SWOT:

1) Internal Factor Analysis:

A. Strengths (Strengths):

1. Production Volume and Value. The production of floating net cages for 2020 has increased from 2019, from 2480 to 7,044 ton, although it had decreased in 2018 by 2530 ton, which in 2017 the production volume reached 2680 ton. Production value continues to increase by IDR. 2000 - IDR, 3000 per year. In 2017, IDR.22,000 / kg until 2020, reaching a price of IDR. $27,000 / \mathrm{kg}$.

2. Potential Aquatic Resources. Banjar Regency has the potential of fisheries and marine resources which are very potential to be developed. Banjar Regency is also one of the 5 regencies / cities in South Kalimantan province that has the potential for public waters and marine waters. In addition, Banjar Regency has also become one of the pilot Minapolitan areas for catfish commodities. This potential resource has been utilized by the community for fishing and cultivation activities.

3. Facilities and Infrastructure. The facilities consist of an independent feed-making area and infrastructure consisting of a group meeting place. such as the Extension Post building / office, the Fish Processing Unit (UPI) building, the ice factory, the Integrated Fish Health Post (Posikandu) and fish rearing ponds which are planned as a vehicle for demonstration plot fish maintenance and fish marketing buildings (indoor and outdoor).

4. Strong will to increase knowledge. Motivation and a strong desire and curiosity encourage the community to increase knowledge about how to manage floating net cages with an environmental perspective.

5. Fish cultivator groups. Fish cultivator groups and community watchdog groups play an active role in implementing environmentally friendly floating net cage cultivation. 
6. Local Government Policies. Government policies that support the development of floating net cages include: Law no. 32 of 2004, Law no. 27 of 2007, Law no. 45 of 2009,; Government Regulation Number 38 of 2007; Government Regulation Number 8 of 2008; Presidential Regulation Number 2 of 2015; Regulation of the Minister of Home Affairs Number 54 Year; Regulation of the Minister of Marine Affairs and Fisheries of the Republic of Indonesia, Number 06 / men / 2010; Banjar Regency Regional Regulation Number 5 of 2016; Banjar Regency Regional Regulation Number 3 of 2013.

b. Weaknesses:

1. Human Resources. The education level of most job seekers in Banjar Regency from year to year is high school education, around $55 \%$ of the total job seekers. Lack of competency level and farmer knowledge regarding sustainable and sustainable floating net cage cultivation.

2. Management of floating net cages. The implementation of good pond management (Best Management Practices) has not been optimally applied to fish ponds in Banjar Regency because the floating net cages are placed in a shallow area in the bay at the edge of the reservoir, this is dangerous for fish because at the time of upwelling (water rotation from bottom to above and vice versa) especially accompanied by waves and wind, the bottom layer of water (lots of poison and low oxygen) is very easily stirred up causing the death of fish. Upwelling often occurs at the beginning of the rainy season (Utomo, 2013).

3. Farmers' participation in controlling floating net cage fish culture. The low level of farmer participation in controlling the fish cultivation of floating net cages is not optimal

4. Institutional Assistance. Institutional assistance in this case is an effort to improve the institutional effectiveness of floating net cage fishpond farmer groups, to conduct training and assistance from field agricultural extension workers because it is still not optimal.

5. Functions of fish cultivator groups. The implementation of the function of fish cultivator groups has not been optimally utilized for the development of sustainable and sustainable floating net cage cultivation with good quality (export quality).

Table 2 - Internal Strategy Factor Matrix

\begin{tabular}{|c|c|c|c|c|}
\hline Internal Strategy Factors & Weight & Rating & Score & Comments \\
\hline \multicolumn{5}{|l|}{ STRENGTH(S): } \\
\hline - Production Value and Volume & 0,15 & 3,60 & 0,54 & $\begin{array}{l}\text { - Increasing pond production is the } \\
\text { key to the success of aquaculture } \\
\text { development }\end{array}$ \\
\hline - Potential of Aquatic Resources & 0,15 & 3,50 & 0,42 & $\begin{array}{l}\text { - Aquaculture land is still very } \\
\text { potential }\end{array}$ \\
\hline - Facilities and infrastructure & 0,08 & 3,30 & 0,26 & - Its utilization must be optimal \\
\hline $\begin{array}{l}\text { Strong will to increase } \\
\text { knowledge }\end{array}$ & & 3,20 & 0,25 & $\begin{array}{l}\text { - Must be supported by mentoring } \\
\text { and training in good aquaculture, }\end{array}$ \\
\hline - $\quad$ Fish cultivator group & 0,12 & 3,40 & 0,34 & $\begin{array}{l}\text { - Fish farmer groups that function } \\
\text { optimally will prevent a decrease in } \\
\text { fish productivity }\end{array}$ \\
\hline - Local Government Policies & 0,08 & 3,30 & 0,26 & $\begin{array}{l}\text { - Various fishery policies support the } \\
\text { development of aquaculture ponds }\end{array}$ \\
\hline \multicolumn{5}{|l|}{ WEAKNESS (W): } \\
\hline - Human Resources & 0,08 & 3,00 & 0,24 & $\begin{array}{l}\text { - Need to increase the } \\
\text { professionalism of Human } \\
\text { Resources }\end{array}$ \\
\hline - Fishing Cage Management & 0,06 & 2,50 & 0,15 & $\begin{array}{l}\text { - Implementation of Best } \\
\text { Management Practices (BMP) } \\
\text { needs to be done }\end{array}$ \\
\hline $\begin{array}{l}\text { - Farmers' participation in controlling } \\
\text { fish farming in floating net cages }\end{array}$ & 0,08 & 3,00 & 0,24 & $\begin{array}{l}\text { - It is necessary to increase the } \\
\text { participation of farmers in } \\
\text { controlling fish farming in } \\
\text { floating net cages }\end{array}$ \\
\hline - Institutional Assistance & 0,06 & 2,50 & 0,15 & $\begin{array}{l}\text { - Institutional assistance needs to } \\
\text { be improved }\end{array}$ \\
\hline - Functions of fish cultivator groups & 0,06 & 2,50 & 0,15 & $\begin{array}{l}\text { - Functions of fish cultivator } \\
\text { groups }\end{array}$ \\
\hline $\begin{array}{l}\text { - Implementation of Field Fishery } \\
\text { Extension Functions }\end{array}$ & 0,05 & 2,40 & 0,12 & $\begin{array}{l}\text { - Implementation of Field Fishery } \\
\text { Extension Functions }\end{array}$ \\
\hline TOTAL & 1,00 & & 3,11 & \\
\hline
\end{tabular}


After determining several internal factors, the next step is to develop an internal strategic factor matrix. The results of the calculation of the Internal Strategic Factors Analysis Summary (IFAS) matrix are presented in Table 2.

Based on the results of the analysis on the internal strategy factor matrix, the strength (S) that has the greatest influence on the management of fish farming in floating net cages in Banjar Regency, is the increase in pond production, the key to the success of aquaculture development with a score of 0.54 , while the biggest weakness is willingness. Strong to increase knowledge must be supported by mentoring and training in good aquaculture with each score of 0.25 . The total weighting score of the internal variables (strengths and weaknesses) is 3.13 .

Based on the analysis of the internal SWOT variables put forward by Umar (2001), the position of Banjar Regency in the competition for strategic advantage is the value criteria in the range of $3.01-3.67$, which is in a favorable position. The position of Banjar Regency in the competition with a weighted score / weighted score of 3.11 can be seen in Table 3 .

Table 3 - Internal Variable Analysis

\begin{tabular}{cc}
\hline Value & Competitive position \\
\hline $1,00-1,66$ & (avoid) \\
$1,67-2,33$ & (weak) \\
$2,34-3,00$ & (tenable) \\
$\mathbf{3}, 01-3,67$ & (favorable) \\
$3,68-4,34$ & (strong) \\
$4,35-5,00$ & (dominant) \\
\hline
\end{tabular}

Source: Analysis of Research Results (2021).

2) External Factor Analysis:

a. Opportunities:

1. Demand for Fish Commodities. The increasing demand for fish commodities will be prioritized because it has a very important influence on regional economic development.

2. Spatial Use of Public Water Areas. The management and utilization of the coastal areas of Banjar Regency are in accordance with the zone plan and / or the Regional Spatial Plan (RTRW).

3. The environment for the cultivation of floating net cages. The stipulation of the cultivation area has taken into account the carrying capacity of the environment, so that the pond fishery cultivation area is recommended as an effort to develop an area of control and environmental buffer against the use of space in the scope of the special economic zone.

4. Fish Cultivator Institution. Fish cultivator institutions will make it easier to increase fish production, absorb fish production directly to end consumers, sell better prices and provide incentives to produce.

5. Supporting Institutions. The role of supporting institutions (stakeholders) is very important in supporting the management of floating net cages, which can be morally (labor providers) and materially (marketing and capital) to help the future process be better.

6. Cooperation between institutions managing marine resources. With the existence of the floating marine cage cultivation management program that is environmentally friendly, it will strengthen the synergy between aquatic resource management agencies from the central to regional levels.

b. Threats:

1. Environmental Factors River is increasingly critical. The increasing exploitation of natural resources, such as land conversion, has resulted in the environment becoming increasingly critical. The rest of the feed will settle on the bottom of the water and over time it will cause silting under the floating net cages. Phosphorus and sodium elements over time will accumulate in the waters and will cause nutrient enrichment (eutrophication) which in turn will cause algae blooms. Pollution from fish farming does not only come from escaped feed but from fish waste in the water (Utomo, 2015). 
2. Potential for natural disasters. Lack of public awareness of environmental preservation results in the potential for natural disasters such as floods and river pollution.

3. There is no master plan to control floating net cage cultivation. There is no reference for monitoring and evaluation activities for the management stages of floating net cage cultivation, it is feared that the activity will not run optimally.

4. Conflict Control of water flow. It is feared that water flow control conflicts will result in greater potential for natural disasters such as river pollution and flooding.

5. Lack of public awareness of environmental conservation. Lack of public awareness of environmental conservation will result in river pollution and flooding due to silting of rivers.

6. The absence of cross-service program synchronization. The absence of synchronization of the cross-service program resulted in no regulation regarding the waste from the floating net cages which silts the river which causes an imbalance of environmental impacts for floating net cage activities.

Analysis of external factors / External Strategic Factors Analysis Summary (EFAS), related to threats and opportunities that exist in the Banjar Regency environment. The results of the analysis of external factors are presented in Table 4 below.

Table 4 - External Strategy Factors Matrix

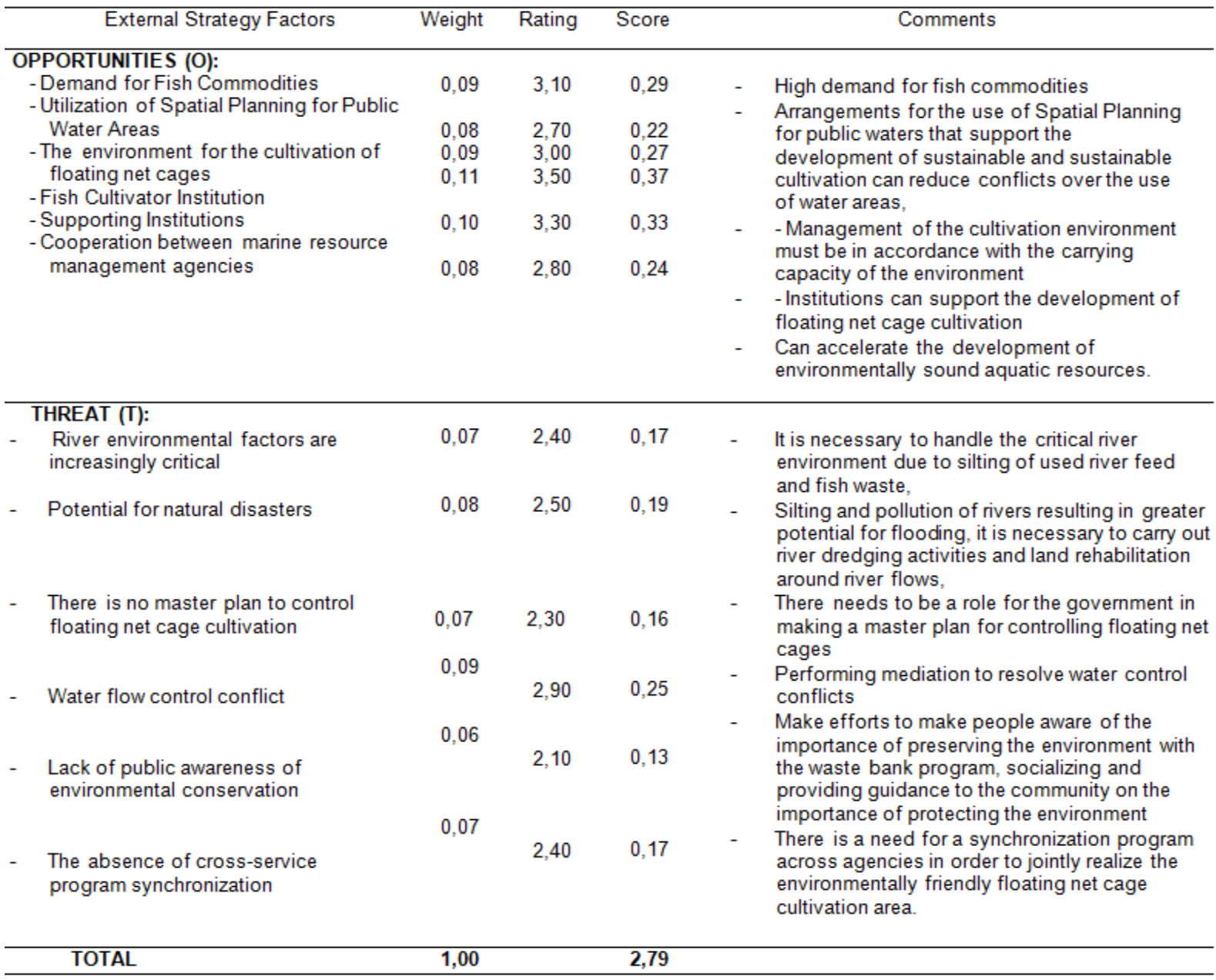

Source: Analysis of Research Results (2021).

Based on the external strategy factor matrix (EFAS), it shows that the greatest opportunity for determining the management of floating net cages in Banjar Regency is the environmental arrangement of floating net cages with a score of 0.37 , while the biggest threat is conflict control of water flow with a score of 0.25 . The total weighted score / weighted value of the opportunities is 1.72 and the threat is 1.07 . After knowing the total 
weighted value, the results of the external variable matrix, the position of Banjar Regency is in adult business. This shows that the level of threat caused by external factors is still low and has a high enough chance. After compiling the IFAS and EFAS matrices, alternative strategies can be formulated based on the SWOT matrix presented in Table 5.

Table 5 - Formulation of Alternative Management Strategies for Fish Farming in Floating Net Cages in Banjar Regency, South Kalimantan Province

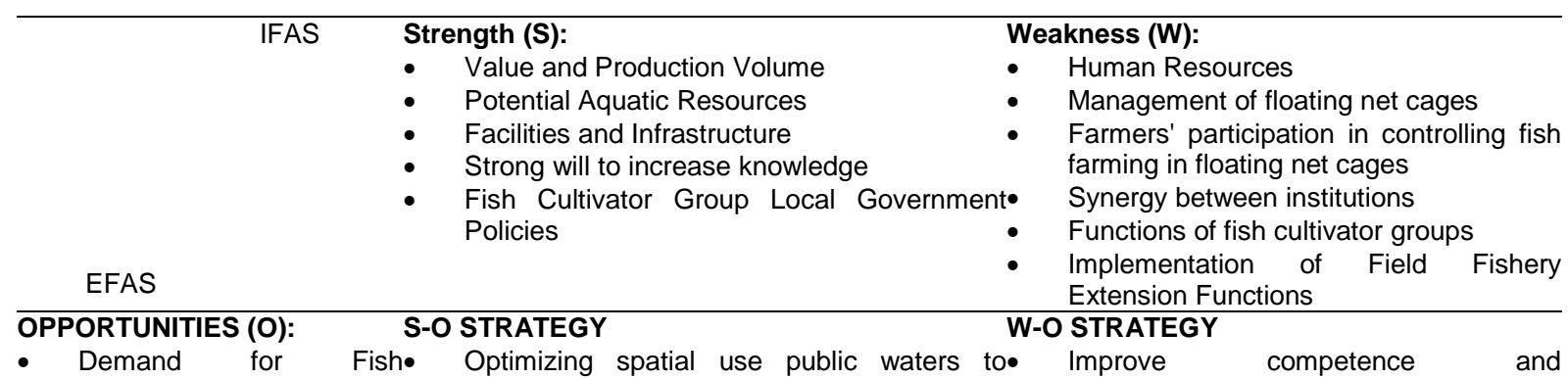

- Demand for Fish• Optimizing spatial use public waters to Commodities determine the arrangement of the

- Utilization of Spatial Planning for Public Water Areas

- $\quad$ The environment for the• cultivation of floating net cages

- Fish Cultivator Institution •

- $\quad$ Supporting Institutions

- Cooperation between marine resource• management agencies

THREAT (T): aquaculture environment according to the carrying capacity of the floating net cages so that land potential can be optimized. Utilizing government policies in the development of floating net cage aquaculture.

Increase the potential of marine resources and take advantage of existing facilities and infrastructure.

Collaborating between aquatic resource management agencies and fish cultivator groups in the development of floating net cage aquaculture.

- River environmental• Optimizing floating net cage management॰ factors are increasingly activities to reduce critical land and reduce critical

- Potential for natural• disasters

the occurrence

pollution and silting of rivers and environmental damage.

Utilization of the coastal river area for pond land in accordance with the carrying capacity and potential of the area through the making• of policies and authorities that consider environmental aspects (ecological) and social.

Creating Special Economic Zones adjacent to floating net cages (extensive / semi• intensive) which can be used as indicators of environmental damage. professionalism of (HR) through training and extension activities.

Increasing the synergy between aquatic resource management agencies and implementing the function of cultivator groups and field fishery extension agents in advancing the floating net cage aquaculture program.

Utilizing funding sources through existing supporting agencies to increase cultivation production results

W-T STRATEGY

Increase the readiness of local governments (DKP) in regulating sustainable and sustainable fishery cultivation business activities.

Preparing competent human resources (HR) global competition and ready to compete with other regions.

Improve coaching and mentoring accompanied by efforts to strengthen capital by facilitating accessibility and increasing number of institutions capital and marketing.

Creating a master plan for control of floating net cage cultivation with environmental insight.

- Synchronize between cross-agency programs, especially with the Department of Environment and Public Works and Spatial Planning.

Analysis of Alternative Floating Mesh Cultivation Management Strategies in Banjar Regency. Based on the results of the weighting and rating, a strategy can be made which is chosen based on the large number of scores from internal and external factors. The results of the calculation of the ranking of alternative strategies formulated in this study are presented in Table 6 below.

Table 6 - Ranking of Alternative Management Strategies for Fishnet Cage Cultivation in Banjar Regency

\begin{tabular}{lllll}
\hline No. & Alternative Strategies & Value & Total Score & Rank \\
\hline 1. & SO (Strengths-Opportunities) & $1,81+1,72$ & 3,53 & 1 \\
2. & ST (Strengths-Treats) & $1,81+1,07$ & 2,88 & 2 \\
3. & WO(Weaknesses-Opportunities) & $0,90+1,72$ & 2,62 & 3 \\
4. & WT(Weaknesses-Treats) & $0,90+1,07$ & 1,97 & 4 \\
\hline
\end{tabular}

Source: Analysis of Research Results (2021). 
Table 7 - Priority Strategies Based on QSPM Analysis

\begin{tabular}{|c|c|c|c|}
\hline No & $\begin{array}{l}\text { Strategy } \\
\text { Priorities }\end{array}$ & TAS & Strategy \\
\hline 1. & I & 6,780 & $\begin{array}{l}\text { - Increase the competence and professionalism of human resources } \\
\text { (HR) through training and extension activities. }\end{array}$ \\
\hline 2. & II & 6,550 & $\begin{array}{l}\text { - Utilization of the coastal area of the river for floating net cage } \\
\text { cultivation land according to the carrying capacity and potential of the } \\
\text { area through the making of policies and authorities that consider } \\
\text { environmental (ecological) and social aspects. }\end{array}$ \\
\hline 3. & III & 6,470 & $\begin{array}{l}\text { - Increase the potential of marine resources and take advantage of } \\
\text { existing facilities and infrastructure. } \\
\text { - Utilizing government policies in the development of floating net cage }\end{array}$ \\
\hline 4. & IV & 6,390 & aquaculture. \\
\hline 5. & $\mathrm{~V}$ & 6,250 & regional autonomy. \\
\hline 6. & $\mathrm{Vl}$ & 6,230 & $\begin{array}{l}\text { - Optimizing pond management activities to reduce river pollution and } \\
\text { environmental damage. }\end{array}$ \\
\hline 7. & VII & 6,170 & $\begin{array}{l}\text { - Increase the readiness of local governments (DKP) in regulation } \\
\text { sustainable and sustainable fishery cultivation business activities. }\end{array}$ \\
\hline 8. & VIII & 6,110 & $\begin{array}{l}\text { - Creating an adjoining Special Economic Zone (KEK) with vanname } \\
\text { shrimp farming (extensive / semi intensive) which can be used as an } \\
\text { indicator of environmental damage. }\end{array}$ \\
\hline 9. & IX & 6,080 & - Prepare human resources (HR) who are competent in global \\
\hline 10. & $x$ & 6,070 & $\begin{array}{l}\text { competition and ready to compete with other regions. } \\
\text { - Increasing guidance and mentoring accompanied by efforts to } \\
\text { strengthen capital by facilitating accessibility and increasing the } \\
\text { number of capital institutions. }\end{array}$ \\
\hline 12. & XII & 6,000 & $\begin{array}{l}\text { - Optimizing the use of spatial planning for coastal areas determine the } \\
\text { cultivation environment according to the environmental carrying } \\
\text { capacity }\end{array}$ \\
\hline & & & $\begin{array}{l}\text { - Utilizing existing funding sources to increase cultivation production } \\
\text { yields. }\end{array}$ \\
\hline
\end{tabular}

Source: Analysis of Research Results (2021).

Based on Table 3, the calculation results of the score of internal factors in the strategic management strategy of floating net cage cultivation in Banjar Regency, namely the strength factor minus the weaknesses, the $X$ value is obtained as the horizontal axis $=1.81-0.90=$ 0.91 so that the $X$ axis value in the SWOT diagram is 0.91 . Based on Table 5 , the calculation results of the score of external factors in the management strategy of floating net cage cultivation in Banjar Regency, the opportunity factor is reduced by threats, the $Y$ value is obtained as a vertical axis $=1.72-1.07=0.65$ so that the value of the $Y$ axis in the SWOT diagram is 0.65 .

The SWOT matrix is built based on the analysis of external and internal strategic factors which are arranged into four main strategies, namely: SO, WO, ST and WT. Based on the results of the calculation of the score on the matrix based on Tables 3 and 5 , the management strategy of floating net cages in Banjar Regency is in quadrant I position (0.91; 0.65). Quadrant I (Strategy Aggressive), that is, with its strengths, it must be able to take advantage of existing opportunities while overcoming all weaknesses that arise and are profitable situations, the organization has opportunities and strengths so that it can take advantage of existing opportunities. Based on the quadrant strategy analysis presented by Rangkuti (2013), the management of floating net cages in Banjar Regency is in the first quadrant. The SWOT matrix strategy quadrant is presented in Figure 1. 


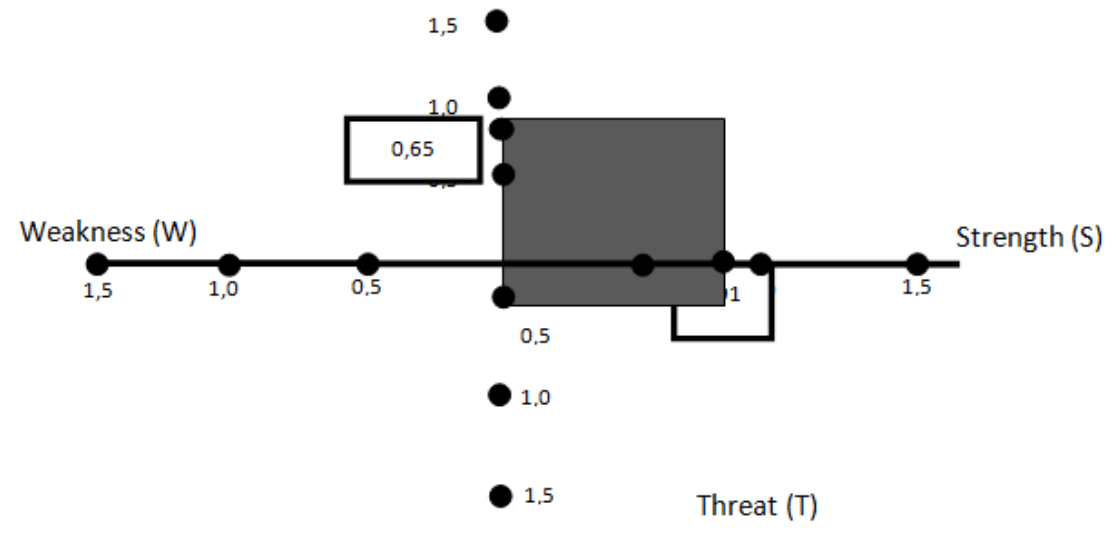

Figure 1 - The Quadrant of Floating Fish Cage Cultivation Strategy in Banjar Regency (Source: Analysis of Research Results, 2021)

Table 9 - Priority Strategies and Action Steps

No.Strategy Priorities Activity Steps

1. Improve the competence and professionalism of human resources Conduct intensive coaching by using existing fishery $(\mathrm{HR})$ through training and extension activities (WO1).

extension workers and field workers, technology assistance by central / regional UPTs and recruiting technology assistants as needed Regular and periodic outreach activities

2. Utilization of coastal areas for pond land that is in accordance with Using land according to its spatial layout and potential the carrying capacity and potential of the area through the making Implementing a waste management system (UPL) and of policies and authorities that consider environmental (ecological) licensing for floating net cages and social (ST2) aspects. existing facilities and infrastructure (SO3).

4. Utilizing government policies in the development of floating net cage aquaculture (SO2).

5. Increasing synergy between aquatic resource management agencies and implementing the function of cultivator groups and field fishery extension agents in advancing the floating net cage aquaculture program. (WO2).

6. Optimizing the management of floating net cages to reduce critical land and reduce pollution and silting of rivers and environmental damage. (ST1).

7. Increase the readiness of local governments (DKP) in regulating Rationalization of science and technology that leads to sustainable and sustainable aquaculture business activities (WT1). the nation's own technology and is based on local

8. Creating Special Economic Zones adjacent to the floating net cages which can be used as an indicator of environmental dama (ST3).

9. Prepare human resources (HR) competent in global competition and ready to compete with other regions (WT2).

10. Increase coaching and mentoring accompanied by efforts to strengthen capital and marketing (WT3)

11 Optimizing spatial utilization coastal areas to determine the cultivation environment according to the carrying capacity of the environment so that land potential can be optimized (SO1).

12 Utilizing funding sources through existing supporting agencies to increase cultivation production results (WO3).
Arrangement of pond area according to caring capacity

Providing production facilities and infrastructure as needed

A good and environmentally friendly floating net cage management application

River aquaculture revitalization activities

Monitoring, controlling and restoring fishery resources activities

Coordination with related agencies in the framework of spatial planning, capital, market development, environmental control, security and others. Implementation of research and development of fisheries technology science

Using healthy quality fish seeds

Maintain and maintain cleanliness of the river Probiotic application to improve environmental quality and suppress pathogenic bacteria

Routine monitoring of fish health

Carry out rehabilitation and reforestation for restoration of critical land

resources

Does not damage the forest, if used for floating net cages

gemust replace / replant according to the rules Dissemination of floating net cage cultivation technology through the provision of dempond in smallholder ponds Implementing a coordinating system for farmers in the area avoid all possibilities that are considered negative Human resource development as a producer of technology and a source of technology users Creation of a competitive market by shortening the chain of trade system from producers to consumers so that farmers get bigger profits.

Socialization of Regional Regulation on the Zoning of Coastal Areas and around river areas

Institutional empowerment to support the management of floating net cages including extension institutions, cultivator groups and finance.

Participatory approach, cooperation and mutual partnership profitable 


\section{CONCLUSION}

Based on the calculation of the internal strategy factor matrix (IFAS), it shows that Kendal Regency is in a safe position (favorable) in the competition and needs to carry out strategic activities, while based on the EFAS matrix it is categorized as speculative. Based on the matrix of internal and external factors, it shows that Banjar Regency is in an investment position (the first quadrant) which means that development needs to be determined by an aggressive strategy (Growth Oriented Strategy). Based on the SWOT analysis, the alternative ranking obtained is the strategy of SO (Strengths-Opportunities) (3.53), ST (Strengths-Treats) (2.88), WO (Weaknesses-Opportunities) (2.62) and WT (Weaknesses-Treats). (1.97).

Based on the analysis of the Quantitative Strategies Planning Matrix (QSPM), the highest strategic priority is the WO1 strategy (TAS value of 6.780 ), namely increasing the competence and professionalism of human resources (HR) with management implications in the form of routine and periodic extension activities while the lowest priority strategy is the WO3 strategy (TAS value of 6,000), namely utilizing existing funding sources to increase cultivation production through participatory approaches, cooperation and mutually beneficial partnerships.

\section{ACKNOWLEDGMENTS}

The authors would like to thank the Department of Marine Affairs and Fisheries (DKP) and the Development Planning Agency (BAPPEDA), the Office of the Central Statistics Agency (BPS) of Banjar Regency who have helped in data collection, both primary and secondary data.

\section{REFERENCES}

1. Chandra, Iwan Binsar Hamonangan Simanjuntak, Fuad Muhammad. 2018. National Seminar on Edusainstek Management Strategies of Sustainable Floating Net Cages in Kedungombo Reservoir, Central Java Master of Environmental Science, Diponegoro University email: iwan7simanjuntak@gmail.com2Departemen of Biology, Faculty of Science and Mathematics, Diponegoro University. ISBN: 978-602-5614-35-4FMIPA UNIMUS 2018.

2. David, F. R. 2004. Strategic Management Concept Concepts.Gramedia, Jakarta.

3. Department of Fisheries and Marine, Banjar Regency. Strategic Plan 2016 - 20121, Aquaculture Statistics 2017 - 2020.

4. Rangkuti, F. (2013) Techniques of Dissecting Business Cases SWOT Analysis: How to Calculate Weight, Rating, OCAI. Jakarta: Gramedia Pustaka Utama.

5. Siagian, M. (2010).Sustainable floating net cage development strategy in Kota Panjang Kampar Riau hydropower reservoir. Journal of Fisheries and Marine Sciences, 15 (2), 145-160.

6. Umar, H. 2001. Strategic Management in Action.Gramedia Pustaka Utama, Jakarta.

7. Utomo, AD. 2013. Determination of the carrying capacity of floating net cages in the Gajah Mungkur reservoir. Dissertation. Environmental Science Study Program, Sriwijaya University, Palembang. $166 \mathrm{p}$.

8. Utomo, AD. 2015. Supporting Capacity of Waters for Fish Cultivation in Floating Net Cages in Kedung Ombo Reservoir. Proceedings.Semnaskan UGM.pMS-04.

9. White P, Phillips MJ, Beveridge MCM. 2013. Environmental impact, site selection and carry-ing capacity estimation for small-scale aquaculture in Asia. In: Ross LG, Telfer TC, Falconer L, Soto D, Agular-Manjarres J (eds). Site selection and carry-ing capacities for inland and coastal aqua-culture. FAO Fisheries and Aquaculture Proceedings, 21: 231251. 